\title{
OCULAR CYSTICERCOSIS
}

\section{An epidemiological study}

\author{
Ehrenfried O. Wittig ${ }^{1}$
}

\begin{abstract}
The objetive of the research was to verify the incidence of the ocular form of cysticercosis among the patients who consulted professionals of the field, during the first statistic inventory accomplished in the State of Paraná, Brazil. The 1996 research was performed through a questionnaire sent to all 220 members of Paraná Ophthalmology Association and to the 17 members of Pathology and Cytology Department of the Paraná Medical Association. A pre-stamped envelop for the return of the answers was included in the package. We received 99 answers from ophthalmologists and 10 answers from pathologists. Retrospective and epidemiological research about the incidences of the ocular cysticercosis in the State of Paraná, added to national related published reports, rendered 95 cases probably adquired in Paraná, 71 of the cases were referred in this research and 24 in prior publication. The most frequent localization was vitreous and subretinal, as literature had already pointed out.
\end{abstract}

KEY WORDS: ocular cysticercosis, Paraná State - Brazil, incidence.

\section{Cisticercose ocular: um estudo epidemiológico}

RESUMO - 0 objetivo da pesquisa foi o de verificar a incidência da forma ocular de cisticercose entre os pacientes que consultam profissionais da área, no primeiro levantamento estatístico realizado no Estado do Paraná. A pesquisa retrospectiva e epidemiológica foi realizada em 1996 através de encaminhamento por correio, de um questionário com envelope com porte pago para resposta aos 220 membros da Associação Paranaense de Oftalmologia e aos 17 membros do Departamento de Patologia e Citologia da Associação Médica do Paraná, dos quais obtivemos 99 cartas-respostas dos oftalmologistas e 10 dos patologistas. A pesquisa retrospectiva, associada aos relatos de outros casos já referidos na literatura nacional, permitiu-nos reunir 95 casos de cisticercose ocular, provavelmente adquiridos no Paraná, sendo 71 casos referidos nesta pesquisa e 24 em publicação anterior. A localização ocular mais frequente foi a vítrea e subretiniana, fato já salientado na literatura.

PALAVRAS-CHAVE: cisticercose ocular, Estado do Paraná, incidência.

Man is the only certain natural host for Taenia solium although other animals apparently can be infected. By chance, man can be the intermediate host for Taenia solium cysticercotic larva. In these circumstances, he may suffer important consequences caused by its presence. Man only shelters Taenia solium cysticercus. As a guest of foreign body, the Cysticercus cellulosae, or the metacystoid form of Taenia solium as the parasitologists prefer to call, can produce immunological reactions with fairly intense inflammatory signs and symptoms in addition to causing compressive and obstructive phenomena in surrounding structures and cavities .

The clinical features of cysticercosis may be a result of just one or hundreds of cysts, which may be distributed in one or several organs and tissues. The combination of the localization within the body, the amount of cysts, the host's immunological reaction, the viability duration of the cyst and the intensity of the inflammatory reaction, may produce fairly exuberant manifestations, especially when it is acting within the meninges, central nervous system or eyeball. Cysts may have diverse localization in the human body and their frequency in tissues and organs may vary. Brazilian ${ }^{1-6}$ and American ${ }^{7}$ studies in general report the encephalic localization as the predominant one. Some European statistics from the beginning of the century ${ }^{8-12}$, when cysticercosis was epidemiologically frequent in that continent showed a predominance of the ocular form (Table 1). Would

Neurology Service, Hospital de Clínicas, Federal University of Paraná (UFPR), Curitiba PR, Brazil: ${ }^{1}$ Associate Professor of Neurology, Medical Clinic Department.

Received 1 September 2000, received in final form 22 June 2001. Accepted 1 July 2001. 
Table 1. Cysticercosis distribution in France.

\begin{tabular}{lcclcr}
\hline \multicolumn{2}{c}{$\begin{array}{l}\text { Vosgien (1911) } \\
\text { cysts - 807 cases }\end{array}$} & \multicolumn{2}{c}{$\begin{array}{c}\text { Volovatz (1902) } \\
\text { cysts - 414 cases }\end{array}$} \\
\hline Eyes \& appendage & 372 & $(46.0 \%)$ & Eyes \& appendage & 248 & $(59 \%)$ \\
Nervous system & 330 & $(41 \%)$ & Nervous system & 149 & $(35 \%)$ \\
Skin \& subcut. cel. & 51 & $(6 \%)$ & Others & 1 & $(4.1 \%)$ \\
Muscles & 28 & $(3 \%)$ & & & \\
Other organs & 26 & $(3 \%)$ & & & \\
\hline
\end{tabular}

the encephalic predominance be a result of larval adaptation modified after its introduction in America?

Human and animal cysticercosis are frequently encountered in Paraná State, although there has been a progressive decline ${ }^{13}$. The neurologic form is more predominant than the ocular or cutaneous-muscular ones. National literature ${ }^{1-4}$ describes more than 2500 cases of the neurologic form in Paraná State.

This epidemiological research sought to verify the prevalence of this ocular form of larval infection in Paraná, a State with 9258813 inhabitants (1998).

\section{METHOD}

The 1996 research was performed through a questionnaire sent to all 220 members of Paraná Ophthalmology Association and to the 17 members of Pathology and Cytology Department of the Paraná Medical Association. A pre-stamped envelop for the return of the answers was included in the package. We received 99 answers from ophthalmologists and 10 answers from pathologists, (Table 2). Most of the professionals of these two specializations in the State are affiliated to both associations. The intention of this research was to verify statistical changes in this last century, when at least, in its beginning, the scientific studies used to show the ocular form predominance.

\section{RESULTS}

Ninety letters were received from the ophthalmologists (40.9\%) and 10 from the anatomopatho-
Table 2. Questionnaire model.

I - Have you already diagnosed any case of ocular cysticercosis? Yes No

II - If yes, how many cases?

III - Which was the local, side and number:
A) Extra Ocular
Right site
Left site
1 - palpebral
2 - sub-conjuntural
3 - orbital
4 - lacrimal g.
B) Intra Ocular 1 - Anterior Chamber
a) cornea
b) aquoso humor
c) iris
d) crystalline
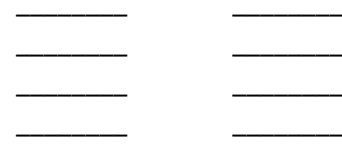
Right site
Left site
2 - Posterior Chamber
a) vítreos humor
b) subhyaloidal
c) subretinal
d) subchoroidal
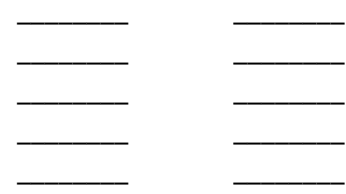

IV - The diagnostic was obtained through:

Physical examination

surgery

Anatomopathologic examination

serologic test

V - Was there associated cysticercosis in other local or organs?

$\mathrm{VI}$ - Specify which were the most important ocular manifestations?

Table 3. Analysis of information received.

\begin{tabular}{lclc}
\hline Ophthalmologists & Answers & Anatomopathologists & Answers \\
\hline Total of answers & $90 / 220(40.9 \%)$ & Total of answers & $10 / 17(58.8 \%)$ \\
Positives & $31 / 90(34.4 \%)$ & Positive & $0 / 17(0 \%)$ \\
Negatives & $59 / 90(65.5 \%)$ & Negative & $10 / 17(100 \%)$ \\
Total of cysticercus & 71 cysts & Total of cysticercus & 0 cases \\
& & Cities of origen & \\
Curitiba & 19 professionals & Apucarana & 1 professional \\
Ponta Grossa & 3 professionals & Francisco Beltrão & 1 professional \\
Castro & 2 professionals & Guarapuava & 1 professional \\
Londrina & 2 professionals & Irati & 1 professional \\
Maringá & 2 professionals & & \\
\hline
\end{tabular}


Table 4. Number and topographic distribution of the cases (1916-1996).

\begin{tabular}{|c|c|c|c|c|}
\hline \multirow[t]{6}{*}{ A) } & Extra ocular & Right site & Left site & \\
\hline & 1 - palpebral & 0 & 1 & \\
\hline & 2 - sub-conjuntural & 0 & 2 & \\
\hline & 3 - orbital & 0 & 3 & \\
\hline & 4 - lacrimal g. & 0 & 0 & \\
\hline & & $0(0 \%)$ & $6(8.4 \%)$ & \\
\hline \multirow[t]{14}{*}{ B) } & Intra ocular & & & \\
\hline & 1 - Anterior chamber & & & \\
\hline & a) cornea & 0 & 0 & \\
\hline & b) aquoso humor & 3 & 0 & \\
\hline & c) iris & 0 & 0 & \\
\hline & d) crystalline & 0 & 0 & \\
\hline & & $3(4.2 \%)$ & $0(0 \%)$ & \\
\hline & 2 - Posterior chamber & & & Not informed site \\
\hline & a) vítreos humor & 22 & 9 & $2(2.8 \%)$ \\
\hline & b) subhyaloidal & 1 & 0 & \\
\hline & c) subretinal & 11 & 10 & \\
\hline & d) subchoroidal & 0 & 0 & \\
\hline & & $34(47.8 \%)$ & $19(26.7 \%)$ & $2(2.8 \%)$ \\
\hline & Subtotal & $37(52 \%)$ & $25(35.1 \%)$ & $2(2.8 \%)=64$ cysts $89.9 \%$ \\
\hline
\end{tabular}

logists (58,8\%). We noticed that most of the professionals who answered the questionnaire worked in University Hospitals and in the biggest private clinics around the State, and that most of the reported cases were observed in the last 80 years (1918-1998).

After analyzing the information received, we gathered the data on Table 3.

The classification of ocular cysts found in this research was made according to the system proposed by Fontan ${ }^{14}$ (Table 4).

\section{DISCUSSION}

The data attained in our research can be compared with those presented by Almeida \& Oliveira ${ }^{15}$ in São Paulo State (Brazil), in 1971. They did an excellent review in the Instituto Penido Burnier Archives, in Campinas (São Paulo). Their material has already been described by Lech ${ }^{16}$ and Queiroz ${ }^{17}$, who reported the findings of Table 5.

The data gathered in our inquiry concerning the ocular topography may also be compared with those reported in 1911 by Vosgien in his thesis (Table 6) $)^{9,11,12}$.

Among European statistics from the beginning of the century that were consulted, the works of $A$. Von Graefe, Vosgien and Volovatz stand out because of the number of cysticercosis cases and because of their significance concerning the ocular form in that period (Table 7).

Statistical distribution of cysts in their ocular form, in that time, represents the findings of a period, of a country and of a limited group of researchers from specialized clinics and coincides with the ophthalmologic surgical therapy emergence. The studies cited, one from Germany and two from France, which are neighboring countries, showed a rising number of cysticercosis cases by the end of last century. Today there are no autochthonous cases in these countries.

Vosgien and Volovatz showed the ocular form prevalence over neurological or another forms (Table 1). This is an interesting fact to be observed since in the American statistics the central nervous system localization was always predominant, although the data came from more recent research. Since in those countries there is hardly any autochthonous human cysticercosis, it is not possible to compare the distribution by periods.

In 1829, in Germany, the first case of ocular cysticercosis was reported by Schott and Soemmering ${ }^{18}$. In 1864, in Brazil, Dr. Pedraglia described the first case of human Cysticercus cellulosae in the eyeball 
Table 5. Cases collected between 1916-1970: 299.

\begin{tabular}{|c|c|c|c|c|c|}
\hline \multicolumn{6}{|c|}{ Cases studied: 283} \\
\hline \multicolumn{6}{|c|}{ Number of affected eyes } \\
\hline \multirow{2}{*}{\multicolumn{6}{|c|}{$\begin{array}{l}\text { RE } 151 \text { eyes LE } 137 \text { eyes } \\
\text { Obs. Binocular (both eyes) }=4 \text { cases }\end{array}$}} \\
\hline & & & & & \\
\hline \multicolumn{6}{|c|}{ Ocular cysticercus topographic localization } \\
\hline \multirow[t]{3}{*}{ a) } & Vitreous & 147 eyes & e) & Anterior chamber & \\
\hline & Clinical Diagnosis & 126 eyes & & Clinical Diagnosis & 3 eyes \\
\hline & Anat.path. Diagnosis & 21 eyes & f) & Subconjunctival & \\
\hline \multirow[t]{3}{*}{ b) } & Subretinal & 90 eyes & & Clinical Diagnosis & 6 eyes \\
\hline & Clinical Diagnosis & 83 eyes & g) & Subcutaneous & \\
\hline & Anat. Pathologic & 7 eyes & & Clinical Diagnosis & 1 eye \\
\hline \multirow[t]{2}{*}{ c) } & Subhyaloidal & & h) & Imprecise local. & 13 eyes \\
\hline & Clinical Diagnosis & 23 eyes & & Binocular & 4 cases \\
\hline \multirow[t]{4}{*}{ d) } & Intraretinal & & & Vitreous + subhyaloidal & 1 case \\
\hline & Clinical Diagnosis & 2 eyes & & Vitreous + subretinal & 2 cases \\
\hline & & & & Subretinal & 1 case \\
\hline & & & \multicolumn{3}{|c|}{ Cysticercus racemous 1 case (6 vitreous vesicles) } \\
\hline
\end{tabular}

Table 6. Ocular cysticercus topographic distribution.

\begin{tabular}{lcclcl}
\hline \multicolumn{6}{l}{ Ocular \& appendage cysticercus. Total: 372 cases } \\
\hline Retinal & 120 & $(32 \%)$ & Orbital & 19 & $(05 \%)$ \\
Vitreous body & 112 & $(30 \%)$ & Iris & 7 & $(02 \%)$ \\
Subconjunctival & 84 & $(23 \%)$ & Cornea & 2 & $(0,5 \%)$ \\
Anterior chamber & 26 & $(07 \%)$ & Crystalline & 2 & $(0,5 \%)$ \\
\hline
\end{tabular}

to the Academia Nacional de Medicina. This study was published in "Annaes Brasileiros de Medicina" Vol. XVI, p.42. ${ }^{18,19}$ Dr.Rubens de Lacerda Manna, a neurologist, reported the first case of neurocysticercosis in Paraná State in 1945, to the Paraná Medical Association. In 1923, Nercolino Machado thesis ${ }^{18}$ in São Paulo referred to the first 25 cases of ocular cysticercosis, collected from various papers published in national literature. He found 9 subretinal, 8 vitreous, 5 conjunctival and 3 located in the anterior chamber.

If we consult the works of Lech ${ }^{16}$, Queiroz ${ }^{17}$ and Almeida \& Oliveira ${ }^{15}$ (and other ophthalmologists) about the ocular or ophthalmologic cysticercosis form in Brazil, we will notice that their statistics were similar to the best statistical works concerning the neurological form described at that time. But they were also based on aberrant ophthalmological statistics. Because of the surgical therapy and the good reputation of the hospital, there was a great national flow of patients to the Ophthalmologic Institute (Penido Burnier), where the studies of the three authors originated.
Some old research can illustrate the comparison between the statistical frequency of ocular and neurological forms. Andrade ${ }^{20}$, in his dissertation for the Rio de Janeiro Medical School (1908), reports 2 cysticercosis cases with neurological manifestations. In one, the necropsy was incomplete. Tretiakoff \& Pacheco e Silva, working in Juquery Hospital (São Paulo), a great psychiatric hospital in 1924, found in 250 necropsies, 9 brain cysticercosis cases ${ }^{6}$. Toledo Galvão ${ }^{19}$, in his thesis from 1928 (São Paulo), found in 1248 necropsies, perfomed in the São Paulo Medical School and Juquery Hospital, 26 cases of brain lodging. In Rio de Janeiro's Hospital dos Alienados (1934), Hélion Póvoa observed only 11 cases of brain cysticercosis among 1163 necropsies ${ }^{21}$. Pinheiro e Mello21 (1941) working in the same hospital, after Póvoa's studies, found 2 cases of neurologic cysticercosis in 465 necropsies performed at Instituto de Neurologia do Rio de Janeiro. Monteiro Salles (1934) in his thesis about cysticercosis presented at São Paulo Medical School, reported 15 clinical observations of brain cysticercosis and 7 cases found in necropsies ${ }^{6}$. 
Table 7. Ocular cysticercosis topographic distribution according to statistics of several authors.

\begin{tabular}{|c|c|c|c|c|c|c|c|c|c|}
\hline Ocular cysticercosis & & & Cases & Vitreous & $\begin{array}{l}\text { Sub- } \\
\text { retinal }\end{array}$ & $\begin{array}{c}\text { Vit./sub- } \\
\text { retinal }\end{array}$ & $\begin{array}{c}\text { Sub- } \\
\text { conjunt. }\end{array}$ & $\begin{array}{c}\text { Ant- } \\
\text { chamber }\end{array}$ & Orbital \\
\hline Von Graefe ${ }^{10}$ & Germany & 1866 & 179 & 90 & 80 & - & 5 & 3 & 1 \\
\hline Volovatz $^{8}$ & France & 1902 & 248 & - & - & - & - & - & - \\
\hline Vosgien ${ }^{9,13}$ & France & 1911 & 372 & 112 & 120 & - & 84 & 26 & 19 \\
\hline Galvão ${ }^{19}$ & Brazil & 1928 & 21 & - & - & 21 & - & - & - \\
\hline Laigner-Terrasse 22 & France & 1932 & 35 & - & - & 26 & 7 & 1 & - \\
\hline Michaeil25 & Romania & 1935 & 11 & - & 10 & - & - & 1 & - \\
\hline Queiroz $^{17}$ & Brazil & 1945 & 92 & 42 & 41 & - & 7 & 2 & - \\
\hline Lech $^{16}$ & Brazil & 1949 & 116 & 51 & 44 & - & 7 & 2 & 1 \\
\hline Tolkovskey ${ }^{22}$ & Russia & 1951 & 1216 & - & - & $73 \%$ & - & - & - \\
\hline Fontan ${ }^{14}$ & Mexico & 1964 & 70 & 29 & 31 & - & 7 & 2 & 1 \\
\hline Malik $^{23}$ & India & 1968 & 110 & 11 & 1 & - & 10 & - & - \\
\hline Almeida $^{15}$ & Brazil & 1971 & 283 & 147 & 90 & - & 6 & 3 & - \\
\hline Kapoor $^{22}$ & India & 1977 & 87 & - & - & 17 & $63 \%$ & 4 & 2 \\
\hline
\end{tabular}

Therefore, a simple statistical presentation may not represent the reality of the situation. Some countries situated in the same meridian and parallel have different disease incidence rates. This phenomenon has been explained by climate, cultural, religious or economic factors. In the USA and Europe taeniasis and human cysticercosis were eliminated in the last fifty years, mainly by educational modifications in the hygienic habits of the population. No more autochthonous cases are found in these places. In 1911, Gomes Faria referred, through coprologic tests, to the infrequency of Taenias (especially solium) in the population of Rio de Janeiro ${ }^{16}$. Concerning this, Lech Júnior"16 (1949) stated, "while there is Taenia solium, cysticercosis will be prevalent, although both prophylaxis are easily executed".

In the ocular form the cysts are lodged in the orbital structures. In Tables 6 and 7 and in the statistics presented by Almeida \& Oliveira ${ }^{15}$, the site variation was shown with retinal and vitreous predominance. Nevertheless, in India $63 \%$ of the ocular cases described were subconjunctival ${ }^{22}$. We do not have an explanation for these findings. According to most authors, in the topographic distribution of head cysticercosis the central nervous system and eyeball localization prevails because of the disposition of the cervical arteries and the amount of cephalic blood flow. The left side predominance, mentioned by several authors, is due to a more direct disposition of blood on the left side. This argumentation may not be true since the investigation about the cutaneousmuscular form has not been so systematically undertaken.
It is possible that the cutaneous-muscular form has a higher incidence than that reported in published studies, but because of its small clinical manifestation it has not been routinely examined neither clinically nor radiologically. Corroborating these facts, Malik et al. ${ }^{23}$ and Dixon \& Lipscomb ${ }^{24}$ studying the disease more systematically found the cutaneousmuscular form predominant.

It is understood that the statistical prevalence of the ocular form in the beginning of the century was due more to the emergence of surgical therapy and the possibility of an easy diagnosis than to the scarceness of other forms. Because the ocular cases determine acute and important ophthalmic or painful clinical manifestations, it was possible to diagnose the processes early and rapidly ${ }^{25}$. Probably, the concentration of well equipped ophthalmologic clinics (the ophthalmoscope had already been invented, improving the accuracy of the diagnosis) in big cities had determined the predominance of the ocular form. Cysticercosis in the brain and other organs and tissues normally does not show clinical features and it is only verified through necropsies or image studies such as radiography, tomography and magnetic resonance.

Analyzing the data collected in our research, a difficulty to evaluate the information was clearly observed. Because some information was incomplete, and some were given from memory, it was difficult to consult or recover the data. Duplicity of information about the same case and loss of records about other cases are possible. Items IV, V and VI of the questionnaire were not analyzed because the 
data was insufficient for a statistic analysis. In the anatomopathologists records this fact may be well observed because none of them informed the record or analysis of an ocular cysticercosis case. This probably was due to a flaw in the nosologic filling of the material. Through personal contact with some ophthalmologists and the applied questionnaire, we found out that they frequently did not send the surgical material for laboratory testing because "there were no doubts" about the etiology of the problem. Only three ophthalmologists mentioned sending the surgical piece to antomopathological analysis. Nonetheless, the survey represents the reality quite well and allows us to have a broad view of the problem.

In our research in Paraná State (Brazil) we observed 71 ocular cysticercosis cases probably acquired in our State, in the period 1916-1996. Almeida \& Oliveira ${ }^{15}$ examined and referred 24 other cases of people resident in Paraná state in his studies at Penido Burnier Institute (São Paulo State, 1971), making a total of 95 cases. This collection of ocular cases is significantly smaller than the already reported neurological cysticercosis cases in Paraná State ${ }^{1-4}$.

In Brazil, except for the research done by Almeida \& Oliveira that reported a great number of cases, we were able to verify only 1 to 8 cases $^{26-29}$. A comparison among studies from several countries does not show significant statistical or topographical modifications.

Ocular cysticercosis is, in most cases, diagnosed through anamnesis, physical examination entailing ophthalmoscopic evaluation, biomicroscopy, transillumination, direct and indirect ophthalmoscopy. Thus, in many cases it is possible to identify a suspected alteration and in others to see the cystic larva alive and moving in the aqueous or vitreous humor.

Nowadays, computerized tomography, magnetic resonance and sonography give us more elements for diagnosis. The final etiologic confirmation is given by macro and/or microscopic anatomopathological analysis. Although infrequent, the association between the ocular form with other localization has not been sought most of the time, especially the muscular one, which is ordinarily asymptomatic ${ }^{23,24}$.

The main therapeutic procedure for ocular cysticercosis is surgical removal of intact or degenerated cyst. Countless techniques were used according to the localization, time and surgical resources. There is great controversy concerning the use of drugs. The more recommended cysticides have been praziquantel and albendazole, isolated or in association. There has been some advantage for the use of al- bendazole because of its lower price and apparent higher effectiveness ${ }^{29,30}$. Dexamethasone and dexachlorfeniramine (antihistaminic) should be used as supporting treatment. Cysticides have little use in intraocular cysts because the penetration of therapeutic substances there is difficult.

\section{REFERENCES}

1. Narata AP, Arruda WO, Uemura E, et al. Neurocisticercose: diagnóstico tomográfico em pacientes neurológicos. Arq Neuropsiquiatr 1998; 56:245-249.

2. Bruck I, Antoniuk S, Figimura S, Mogami K, Miyaki M. Neurocysticercosis: analysis of 114 patients (abstr ) Pediatric Neurol 1994;11:149.

3. Arruda WO, Menezes MS, Antoniuk AS. Neurocisticercose: diagnóstico e tratamento. Rev Bras Neurol 1996;32:15-20.

4. Almeida SM, Torres LFB, Stegoni MM, Vicente L, Werneck LC. Neurocisticercose: estudo retrospectivo de laudos de necrópsia (19771994) (abstr). Arq Neuropsiquiatr 1994;52(Suppl):P-009.

5. Spina-França A. Cisticercose do sistema nervoso central. Rev Paulista Med 1956;48:59-70

6. Canelas HM. Neurocisticercose: incidência, diagnóstico e formas clínicas. Arq Neuropsiquiatr 1962;20:1-16.

7. Sotelo J, Guerrero V, Rubio F. Neurocysticercosis: a new classification based on active and inactive form: a study of 753 casos. Arch Intern Med 1985;145:442-445.

8. Volovatz E. Ladrerie ou cysticercose chez l'homme. Thèse, Faculté de Medecine de Paris. Paris, 1902 (citado por Brumpt).

9. Vosgien Y. Le Cysticercus cellulosae chez l'homme et chez les animaux. Thèse, Faculté de Medecine de Paris. Paris, 1911.N 373 (cit por Rey e por Brumpt).

10. Von Graefe A. Bemerkungen über Cysticercus. Archv fur Ophtalmol Zwölfeter Jahrgang 1866;12:174 (citado por Queiroz).

11. Rey L. Cisticercose humana. Revista Roche 1958; $n^{\circ} 7$ a 11:182-284.

12. Brumpt E. Précis de parasitologie. Ed.3. Paris: Masson, 1923:408-434.

13. Giovannoni M, Fernandes BF, Buseti ET, França DC, Wittig EO. Considerações sobre a hidatidose e cisticercose em suínos nos Estados do Paraná e Santa Catarina.Arq Biol Tecnol Curitiba 1972;15:73-85.

14. Sanchez Fontan R. Cisticercosis ocular. These, Faculdad de Medicina de la Universidad Nacional Autonoma de Mexico. Mexico, 1964.

15. Almeida AA, Oliveira JEB. Cisticercose ocular. Rev Inst Med Trop São Paulo 1971;13:1-8.

16. Lech J. Cisticercose ocular. Arq Inst Penido Burnier 1949;8:13-64.

17. Queiroz LS. Cisticercose ocular. Arq Inst Penido Burnier 1945;7:129-150.

18. Machado NR. Contribuição ao estudo da cysticercose ocular no Brasil. These, Faculdade de Medicina e Cirurgia de São Paulo. São Paulo, 1923:1-118.

19. Galvão ST. Incidencia e prophylaxia da cysticercose e do kysto hydatico em São Paulo. These, Faculdade de Medicina de São Paulo. São Paulo, 1928;1-52.

20. Andrade AD. Pequena contribuição ao estudo da cysticercose humana. These, Faculdade de Medicina do Rio de Janeiro. Rio de Janeiro, 1908;1-80.

21. Pinheiro J, Mello AR. Considerações sobre a cisticercose cerebral. Arch Bras Med 1941;31:192-216.

22. Kapoor S. Ocular cysticercosis in India. Trop Geogr Med 1978; 30:253-256.

23. Malik SRK, AK Gupta AK, Choudhry S. Ocular cysticercosis. Am J Ophthalmol 1968;66:1168-1171.

24. Dixon HBF, Lipscomb FM. Cysticercosis: an analysis and follow-up of 450 cases. Special Report Series. Medical Research Council 1961; 299:1-58.

25. Michäil D. La cysticercose oculaire en Roumanie. Ann d'Oc 1935;172:385-402.

26. Fialho A. Caso de cisticercose ocular sub-conjuntival. A Patologia Geral Maio-1918 (cit Machado NR)

27. Adam A Neto, Setter V. Cisticercose ocular: análise de oito casos. Rev Bras Oftalmol 1983;42:205-215.

28. Almeida W. Contribuição ao estudo clínico da cysticercose cerebral. Arq Bras Psiquiat Neurol Med Legal 1915;11:229-264.

29. Nóbrega JPS. Neurocisticercose: tratamento clínico. In Machado LR et al. Neuroinfecção 1996. São Paulo: Clínica Neurológica HC/FMUSP, 1996:219-226.

30. Flisser A. Cysticercosis: present state of knowledge and perspectives. New York: Academic Press, 1982. 